\section{Enantioselective Dearomatization of}

\section{Pyridines with Styrene-Derived Nucleophiles}

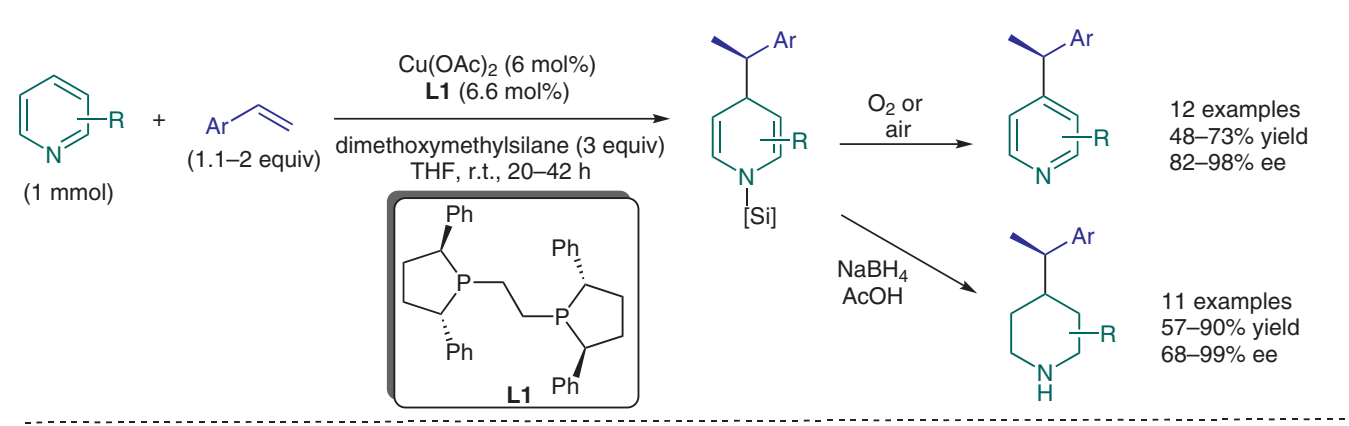

\section{Selected examples:}<smiles>CC(c1ccccc1)c1ccncc1</smiles>

$64 \%$ yield, $90 \%$ ee<smiles>CC(c1ccccc1)c1ccncc1C#C[I-]F</smiles>

$55 \%$ yield, $82 \%$ ee<smiles>CC(c1ccncc1)c1ccccc1F</smiles>

$72 \%$ yield, $93 \%$ ee<smiles>C[C@@H](c1ccnnc1)c1cccc(Cl)c1</smiles>

$48 \%$ yield, $94 \%$ ee<smiles>Cc1cnccc1[C@H](C)c1ccccc1</smiles>

$61 \%$ yield, $82 \%$ ee<smiles>COCCC(c1ccccc1)c1ccnnc1OC</smiles>

$58 \%$ yield, $93 \%$ ee

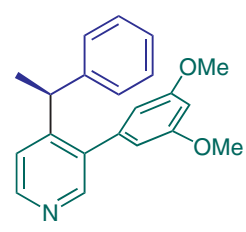

$73 \%$ yield, $94 \%$ ee

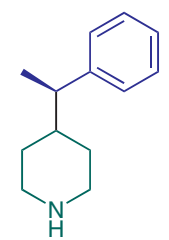

$86 \%$ yield, $90 \%$ ee<smiles>CC(c1cccc(F)c1)C1CCNCC1</smiles>

$89 \%$ yield, $91 \%$ ee on $10 \mathrm{mmol}$ scale $81 \%$ yield, $89 \%$ ee<smiles>Clc1cccc(C(CCN2CCN(Cc3ccccc3)CC2)C2CCNCC2)c1</smiles>

$64 \%$ yield, $85 \%$ ee
$90 \%$ yield, $76 \%$ ee

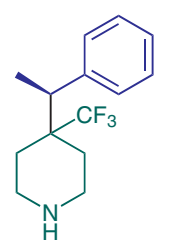

Category

Metal-Catalyzed

Asymmetric

Synthesis and

Stereoselective

Reactions

\section{Key words}

copper catalysis

dearomatization

pyridines

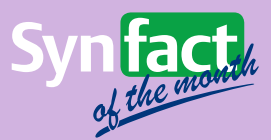

Significance: Dearomatization of heteroaromatics is a valuable transformation in organic chemistry to create new carbon-carbon bonds. Herein, Buchwald and co-workers report the dearomatization of pyridines with a chiral benzylic copper species generated through an enantioselective copper hydride addition to the corresponding styrene. SYNFACTS Contributors: Mark Lautens, Andrew Whyte Synfacts 2018, 14(07), 0707 Published online: 18.06.2018 Dol: 10.1055/s-0037-1609533; Reg-No.: L06218SF
Comment: The intermediate dihydropyridine could be oxidized to regenerate the pyridine or reduced to give the piperidine scaffold. A variety of substituents could be tolerated on either the styrene or pyridine, including halogens and alkyl or alkynyl groups. The alkene could also be a $\beta$-substituted styrene containing a heteroatom in the alkyl chain. 